\title{
DRASTICAI, a New Index for Groundwater Vulnerability Assessment-A Portuguese Case Study
}

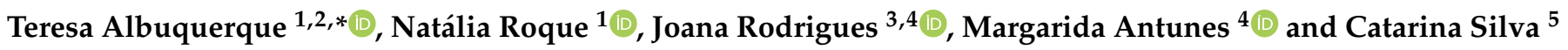 \\ 1 Centro de Estudos de Recursos Naturais, Ambiente e Sociedade, QRural, Polytechnique Institute of Castelo \\ Branco, 6000-084 Castelo Branco, Portugal; nroque@ipcb.pt \\ 2 Instituto de Ciências da Terra, University of Évora, 7000-812 Évora, Portugal \\ 3 Naturtejo UNESCO Global Geopark, 6000-083 Castelo Branco, Portugal; joana225@gmail.com \\ 4 Instituto de Ciências da Terra, University of Minho, 4710-057 Braga, Portugal; imantunes@dct.uminho.pt \\ 5 Faculdade de Ciências, Instituto Dom Luiz, Universidade de Lisboa, 1649-004 Lisbon, Portugal; \\ csilva@fc.ul.pt \\ * Correspondence: teresal@ipcb.pt; Tel.: +35-196-814-1801
}

\section{check for} updates

Citation: Albuquerque, T.; Roque, N.; Rodrigues, J.; Antunes, M.; Silva, C. DRASTICAI, a New Index for Groundwater Vulnerability Assessment-A Portuguese Case Study. Geosciences 2021, 11, 228. https://doi.org/10.3390/ geosciences11060228

Academic Editors

Jesus Martinez-Frias and

Helder I. Chaminé

Received: 12 April 2021

Accepted: 20 May 2021

Published: 25 May 2021

Publisher's Note: MDPI stays neutral with regard to jurisdictional claims in published maps and institutional affiliations.

Copyright: (c) 2021 by the authors. Licensee MDPI, Basel, Switzerland. This article is an open access article distributed under the terms and conditions of the Creative Commons Attribution (CC BY) license (https:// creativecommons.org/licenses/by/ $4.0 /)$

\begin{abstract}
Groundwater vulnerability assessment has become a useful tool for groundwater pollution prevention. Groundwater vulnerability maps provide useful data for protecting groundwater resources. Identification of agricultural patterns is an important issue for optimized land management. The watershed of the Tagus River is the backbone of this study. Naturtejo UNESCO Global Geopark, in the central interior of Portugal, corresponds to a rural area. Intensive agricultural practices showed an increasing trend in the last decades. The method that is most used internationally to assess vulnerability is the DRASTIC index. In this study, the DRASTICAI index is introduced. A new attribute-anthropogenic influence-is added here. Five levels of increasing vulnerability, from low to high, can be recognized here. The municipality of Idanha-a-Nova is most affected by intensive agricultural activities, showing spatial patterns of DRASTICAI with a clear influence of anthropogenic activities, with high needs for groundwater abstraction. A robust assessment of groundwater quality has a key role. Climate change scenarios and water scarcity are important issues in the coming years, and particularly in the studied area. Therefore, optimized groundwater management is essential to consider in policy-making strategies.
\end{abstract}

Keywords: Naturtejo Geopark; groundwater; vulnerability; DRASTIC; DRASTICAI; GIS

\section{Introduction}

Nowadays, groundwater vulnerability assessment has become a useful tool for groundwater pollution prevention. Groundwater vulnerability maps provide useful data for the protection of groundwater resources and serve as a tool for water management, as they allow changes in agricultural practices to be considered and, thus, optimization of land use [1-7].

Groundwater vulnerability assessment is a recognized complex process, since natural conditions and land-use practices vary substantially around the world. Thus, making the associated risk of pollution dependent on specific factors and the available data, two different types of groundwater vulnerability are widely recognized in literature: intrinsic and extrinsic, or specific, vulnerabilities [8]. The first is a function of hydrogeological factors, and the second is defined by adding attributes that define the potential anthropogenic influence. The most widely used method for assessing intrinsic vulnerability is the DRASTIC index [9], as it is easy to calculate and requires a minimum amount of data. The DRASTIC model was developed by the U.S. Environmental Protection Agency (EPA) to assess groundwater contamination potential for the entire United States. The DRASTIC Pesticide uses the same parameters but a different weighting scheme to stress the importance of agricultural activities [9-11]. 
In the last decades, many authors have proposed different extensions of the DRASTIC index, e.g., by testing different approaches of weighting techniques [1]; introducing a DRASTIC calibration technique for the specific contamination by nitrates [2]; or introducing other approaches, such as the modified SINTACS method based on a $\mathrm{NO}_{3}{ }^{-}$and $\mathrm{SO}_{4}{ }^{2-}$ dataset [7]. Another approach is the susceptibility index (SI). This index provides the assessment of the specific vertical vulnerability to pollution mainly due to agricultural activities and, therefore, with high influence of the presence of nitrate. Its computation is based on the DRASTIC, considering four of the original parameters: depth to water (D), annual efficient recharge (R), aquifer media (A), and topography (T), and adding a fifth and new parameter, land use [12].

In the present study, the main objective is to introduce an empirical approach for a modified DRASTIC to assess the vulnerability of a groundwater system in a region where anthropogenic activities are very diverse, from mining activities to intensive agriculture, and where available information is scarce. In other words, how can one approach groundwater management in an inherently complex region that is subject to diverse anthropogenic influences and where scarce information is available? How can one create a possible decision support tool?

The study area is in the center of the Portuguese interior, close to the Spanish border, and belongs to the district, Castelo Branco (Figure 1a). This area largely overlaps with the area of Naturtejo UNESCO Global Geopark, created in 2006, an area of outstanding geological heritage that includes 176 geosites, 9 of which have hydrogeological significance, such as springs, hot springs, fountains, or medicinal water sources [13]. Geographically located within the Central Iberian Zone of the Iberian Massif, it lies at the junction between the Central Cordillera (to the north) and the Alentejo peneplain (to the south).

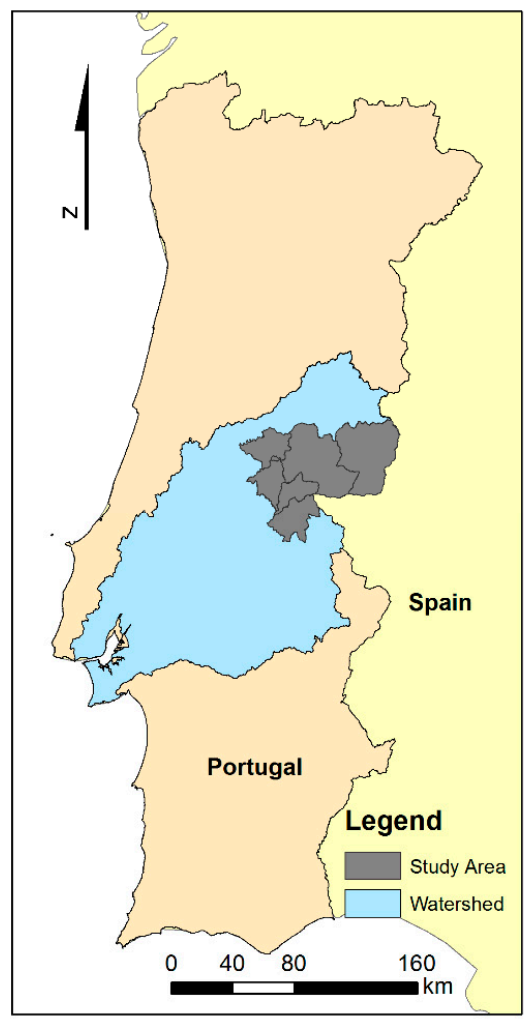

(a)

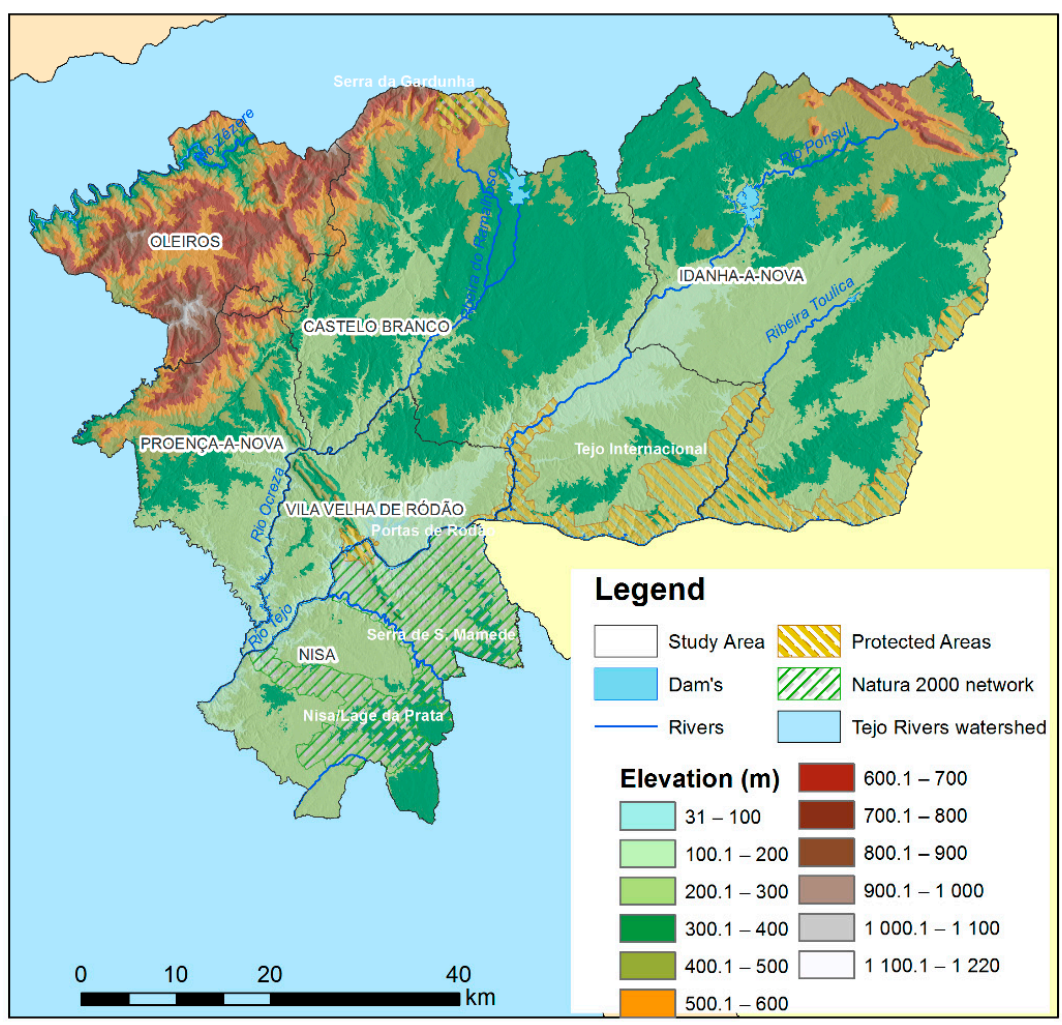

(b)

Figure 1. (a) Study area: Naturtejo Geopark and Tagus watershed; (b) elevation map with the municipalities of: Oleiros, Castelo Branco, Idanha-a-Nova, Proença-a-Nova, Vila Velha de Rodão and Niza; main rivers (Tagus River, Zêzere, and Ocreza); dams (St. ' Agueda and Marchal Carmona); protected areas (Tejo Internacional and Serra de São Mamede, Monumento Natural da Serra da Gardunha e Portas de Rodão); Natura 2000 Network (Serra da Gardunha, Serra de São Mamede, and Niza/Lage da Prata). 
The area under study lies within the hydrographic watershed of the Tagus River, one of the largest hydrologic systems of Western Europe, which traverses almost the entire Iberian Peninsula. This watershed includes rivers such as Zêzere, Erges, Ocreza, Ponsul, or Tagus (which forms the southern border of the district), and streams such as Meimoa, Aravil, or Sertã. The altitude ranges from $31 \mathrm{~m}$, in the lower Tagus river, to $1220 \mathrm{~m}$, in the Gardunha Mountain (Figure 1b). The clime is the Mediterranean, with a hot and dry summer and with mean precipitation ranging from $500 \mathrm{~mm}$ to $800 \mathrm{~mm}$, and a mean temperature between $22.5^{\circ} \mathrm{C}$ and $25^{\circ} \mathrm{C}$ [14].

The oldest bedrock comprises mainly Neoproterozoic and Lower Cambrian, with impermeable metasediments (shales and metagraywackes) from the Beiras Group [15,16] forming wide flattened areas. The catchment is truncated by the Armorican quartzite formation of the Lower Ordovician age [17,18]. Quartzites characterized by fractures and fissures, with minor intercalations of pelite, are the most common lithology. These rocks are found in thick quartzite beds in the ridges of Penha Garcia, Monforte da Beira, Muradal, Unhais-o-Velho ou Talhadas, with the main direction NW-SE directly related to Variscan deformation. Variscan and Ordovician magmatic bodies intruded the bedrock of the Beiras Group in Castelo Branco [19], Penamacor-Monsanto [20], Fundão [21], Covilhã [22], and Oledo [23] (Figure 2a). Continental sediments of the Cenozoic age with variable permeability (arkoses, conglomerates, and breccias) are found in the basins of the Sarzedas and Lower Tagus [24].

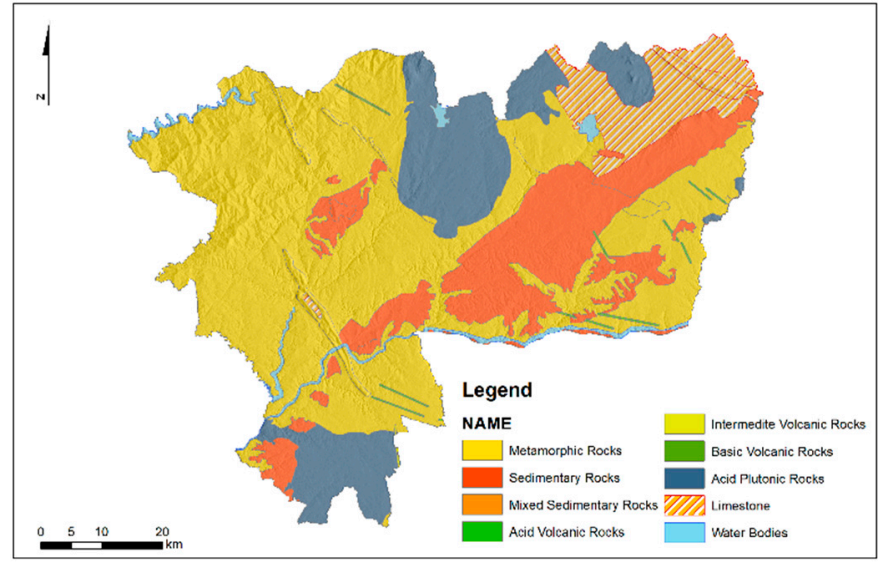

(a)

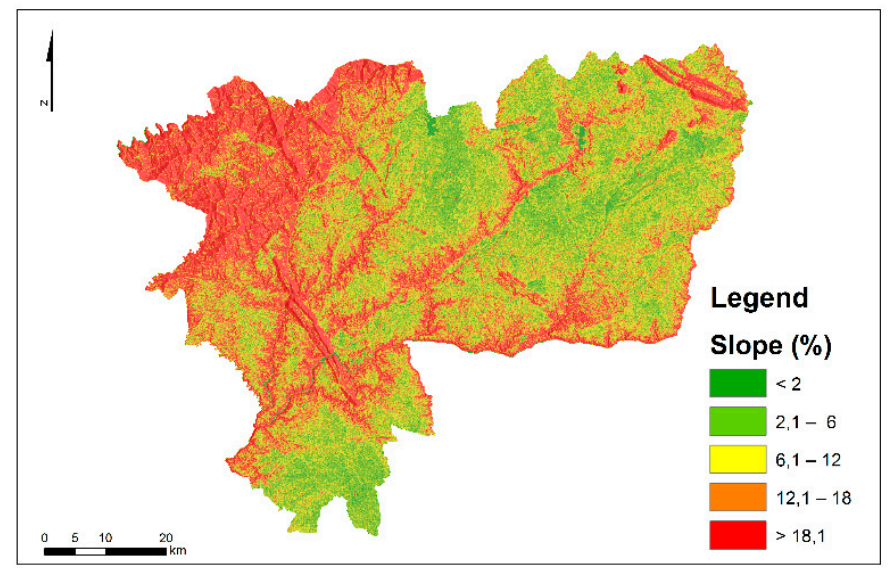

(c)

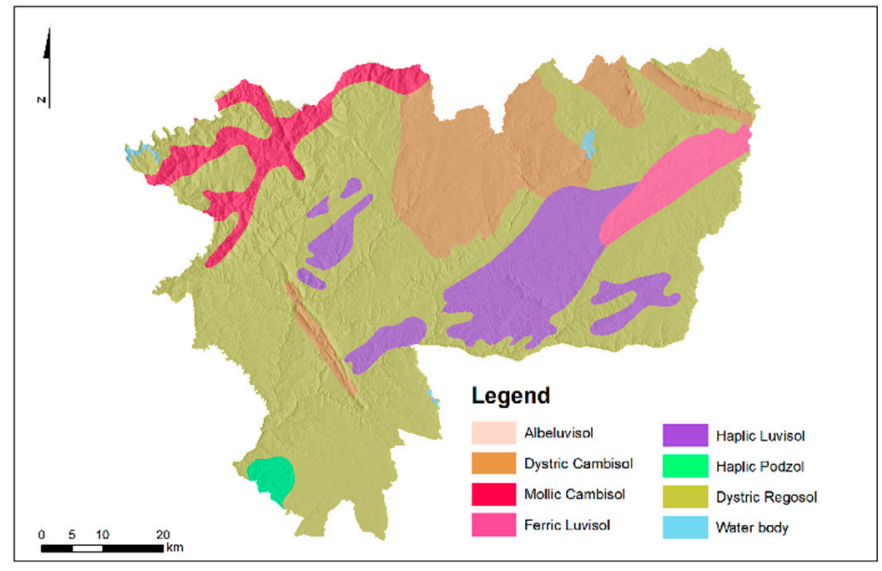

(b)

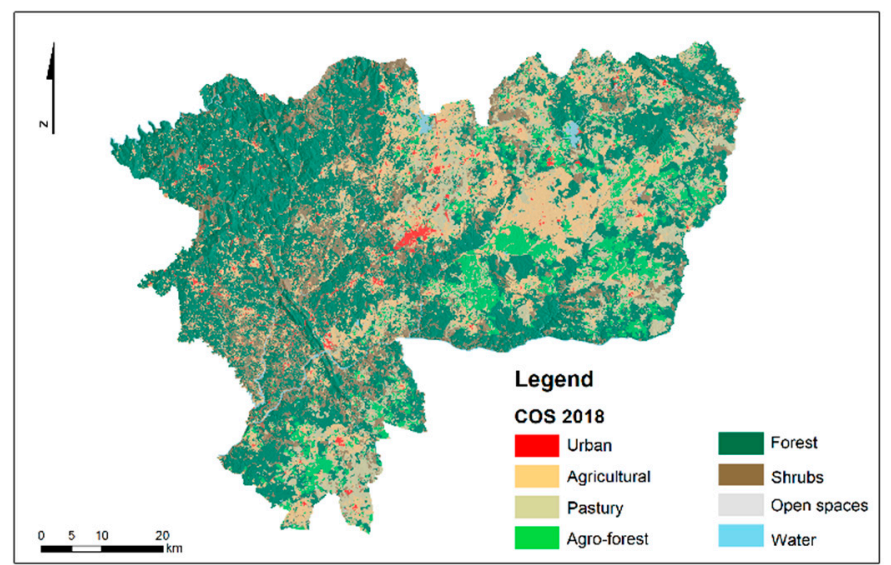

(d)

Figure 2. Base map variables of the study area: (a) lithology, (b) soil, (c) slope, and (d) anthropogenic influence. 
The main objective of this study was to evaluate the vulnerability of groundwater to pollution, more specifically, the watershed of the Tagus River in Naturtejo Geopark (Figure 1), using a modified DRASTIC method in a GIS environment. The modified DRASTIC index (DRASTICAI) was created by adding a new attribute called "anthropogenic influence".

\section{Materials and Methods}

The DRASTIC model is based on the concept of the hydrogeologic environment, which is defined as a composite description of all the major geologic and hydrologic factors that influence and control groundwater movement into, throughout, and out of the area. The acronym represents seven hydrogeologic parameters considered in the assessment process: depth to groundwater (D), aquifer recharge (R), aquifer media (A), soil media (S), topography (T), impact of vadose zone (I), and hydraulic conductivity (C) of the aquifer. Each DRASTIC parameter is evaluated concerning the others to determine the relative importance of each parameter, and is then given a relative weight ranging from 1 to 5 . The most important parameters are given a weight of 5 , while the least important are given a weight of 1 [9] (Tables 1 and 2). The purpose of the DRASTIC index implies the multiplication of each factor weight by its category rating (Table 3), where the ratings (r) reflect the importance of the classes, and the weights $(\mathrm{w})$ reflect the importance of the parameter as follows:

DRASTIC $=\left(D_{\mathrm{r}} \times \mathrm{D}_{\mathrm{w}}\right)+\left(\mathrm{R}_{\mathrm{r}} \times \mathrm{R}_{\mathrm{w}}\right)+\left(\mathrm{A}_{\mathrm{r}} \times \mathrm{A}_{\mathrm{w}}\right)+\left(\mathrm{S}_{\mathrm{r}} \times \mathrm{S}_{\mathrm{w}}\right)+\left(\mathrm{T}_{\mathrm{r}} \times \mathrm{T}_{\mathrm{w}}\right)+\left(\mathrm{I}_{\mathrm{r}} \times \mathrm{I}_{\mathrm{w}}\right)+\left(\mathrm{C}_{\mathrm{r}} \times \mathrm{C}_{\mathrm{w}}\right)$

In this study, an additional parameter was added to the DRASTIC model to represent groundwater vulnerability more accurately by including anthropogenic influence (AI). This new parameter is rated depending on land use and was assigned a weighting value of 5, and the modified DRASTIC index, DRASTICAI, was calculated using the following equation:

DRASTICAI $=\left(D_{\mathrm{r}} \times \mathrm{D}_{\mathrm{w}}\right)+\left(\mathrm{R}_{\mathrm{r}} \times \mathrm{R}_{\mathrm{w}}\right)+\left(\mathrm{A}_{\mathrm{r}} \times \mathrm{A}_{\mathrm{W}}\right)+\left(\mathrm{S}_{\mathrm{r}} \times \mathrm{S}_{\mathrm{W}}\right)+\left(\mathrm{T}_{\mathrm{r}} \times \mathrm{T}_{\mathrm{w}}\right)+\left(\mathrm{I}_{\mathrm{r}} \times \mathrm{I}_{\mathrm{W}}\right)+\left(\mathrm{C}_{\mathrm{r}} \times \mathrm{C}_{\mathrm{w}}\right)+\left(\mathrm{AI}_{\mathrm{r}} \times \mathrm{AI}_{\mathrm{w}}\right)$

where $\mathrm{D}$ is rated depending on the depth of groundwater, $\mathrm{R}$ is rated depending on the recharge rate (net), $\mathrm{A}$ is the aquifer media, $\mathrm{S}$ depends on the kind of soil, $\mathrm{T}$ is rated in relation to the terrain slope (slope), I is rated depending on the hydraulic conductivity of the aquifer on the lithology of the vadose zone, $C$ is the conductivity (hydraulic) of the aquifer, and $\mathrm{AI}$ is anthropogenic influence (Table 1).

Table 1. Assigned weights for DRASTIC parameters (Source: [9]) and DRASTICAI.

\begin{tabular}{cc}
\hline Parameters & Weight \\
\hline Depth & 5 \\
Recharge & 4 \\
Aquifer media & 3 \\
Soil media & 2 \\
Topography & 1 \\
Impact of vadose zone & 5 \\
Hydraulic conductivity & 3 \\
Anthropogenic influence & 5 \\
\hline
\end{tabular}

Table 2. Data type, source, format, and respective references of the DRASTIC/DRASTICAI parameters.

\begin{tabular}{ccccc}
\hline Parameters & Data Type & Source & Format & Reference \\
\hline Depth & Interpolation & SNIRH and IGEM & Table & {$[25,26]$} \\
Recharge & Location Map & ARH Tejo & Raster & {$[27,28]$} \\
Aquifer media & Geology Map & Global Lithological Map & Polygon & {$[29]$} \\
Soil media & Soil Map & database v1.1 & Polygon & {$[30]$} \\
Topography & Elevation Map & Global Digital Elevation Model & Raster & {$[31]$} \\
Impact of vadose zone & Geology Map & Global Lithological Map & Polygon & {$[29]$} \\
Hydraulic conductivity & Driven Soil Map & FAO + 3D Hydraulic DB & Raster & {$[30,32,33]$} \\
Anthropogenic & Land Use 2018 & COS 2018 & Polygon & {$[34]$} \\
influence & Administration & CAOP 2020 & Polygon & {$[35]$} \\
Study Area & & &
\end{tabular}


Table 3. DRASTIC (Source: [9]) and DRASTICAI parameters.

\begin{tabular}{|c|c|c|}
\hline DRASTIC/DRASTICAI & Range & Rating \\
\hline \multirow{5}{*}{ Depth to groundwater (m) } & 30.5 & 1 \\
\hline & $22.9-30.5$ & 2 \\
\hline & $15.2-22.9$ & 3 \\
\hline & $9.1-15.2$ & 5 \\
\hline & $4.6-9.1$ & 7 \\
\hline \multirow{5}{*}{ Recharge rate (net) (mm) } & $<50$ & 1 \\
\hline & $50-100$ & 3 \\
\hline & $100-150$ & 6 \\
\hline & $150-300$ & 8 \\
\hline & $>300$ & 9 \\
\hline \multirow{7}{*}{ Aquifer media } & Metamorphic rocks & \\
\hline & Sedimentary Rocks & 3 \\
\hline & Acid Volcanic Rocks & \\
\hline & Intermediate Volcanic Rocks & 3 \\
\hline & Basic Volcanic Rocks & \\
\hline & Acid Plutonic Rocks & 4 \\
\hline & Limestone & 6 \\
\hline \multirow{3}{*}{ Soil media } & Coarse & 6 \\
\hline & Medium & 9 \\
\hline & Null/No information & 10 \\
\hline \multirow{5}{*}{ Topography (slope) (\%) } & $>18$ & 1 \\
\hline & $12-18$ & 3 \\
\hline & $6-12$ & 5 \\
\hline & $2-6$ & 9 \\
\hline & $<2$ & 10 \\
\hline \multirow{6}{*}{ Impact of the vadose zone } & $\begin{array}{l}\text { Metamorphic Rocks } \\
\text { Sedimentary Rocks }\end{array}$ & 4 \\
\hline & Acid Volcanic Rocks & \\
\hline & Intermediate Volcanic Rocks & 4 \\
\hline & Basic Volcanic Rocks & \\
\hline & Acid Plutonic Rocks & 4 \\
\hline & Limestone & 6 \\
\hline \multirow{3}{*}{ Hydraulic conductivity of the aquifer $(\mathrm{m} / \mathrm{d})$} & $<4.1$ & 1 \\
\hline & $12.2-28.5$ & 4 \\
\hline & $>28.5$ & 6 \\
\hline \multirow{7}{*}{ Anthropogenic influence } & Water body and waste land & 1 \\
\hline & Forest and shrub land & 2 \\
\hline & Built up with very low density & \\
\hline & Agriculture & 5 \\
\hline & Built up with low density & 7 \\
\hline & Built up with medium density & 8 \\
\hline & Built up with high density & 9 \\
\hline
\end{tabular}

For the mention parameters, different data sources were used (Table 2), and the geographical information projected using the EPGS (European Petroleum Survey GroupGeodetic Parameter Dataset) code projection 4326 I WGS 84 reference system. Furthermore, the maps were clipped using the survey area polygon as geometry. ArcGIS 10.3 software was used for computation purposes.

It is worth stressing that the predominant lithology corresponds to metamorphic rocks and mixed sedimentary rocks (in the global lithological map). Concerning soils, the most common are the dystric regosol, haplic aluvisol, and dystric cambisol (in the FAO harmonized soil map). Finally, the map representing the slope classes was computed using the elevation, driven by the SRTM elevation map. The computation was performed in 
degrees, in the Spatial Analyst tool. The land-use map aggregates the characteristics of the land use, namely agricultural, agro-forest, and forest (Figure 2).

The piezometers' network data for Spain and Portugal, between 1986 and 2020, was compiled $[25,26]$, and a point dataset of 23 locations, 13 locations in Portugal and 10 in Spain, was gathered. The inverse distance weighted (IDW) interpolator was used to produce the raster data file containing the depth information, in meters. The recharge layer was gathered from [27], and contains the annual net recharge (mm/year) within a $250 \mathrm{~m}$ cell resolution. Concerning the hydraulic conductivity, a layer driven from SoilGrids included in EU-SoilHydroGrids ver1.0 [32] was downloaded for $2 \mathrm{~m}$ depth from saturated hydraulic conductivity $\mathrm{cm}$ day $^{-1}(\mathrm{KS})$, in a $250 \mathrm{~m}$ cell size.

Furthermore, aquifer media, soil media, impact of the vadose zone, and anthropogenic influence raster layers were constructed in a $250 \mathrm{~m}$ cell resolution, using the ArcMap's polygon to raster tool (Figure S1).

The final DRASTIC and DRASTICAI outputs were computed through map algebra (Figure 3).

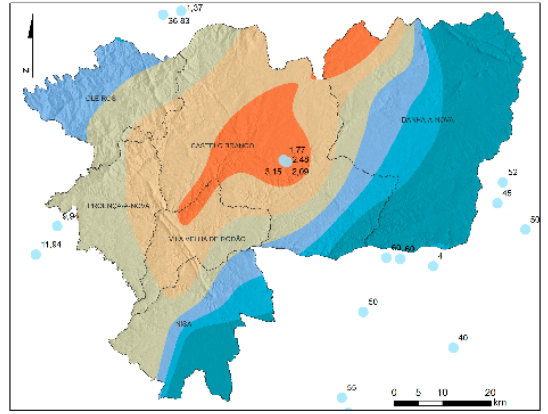

(a)

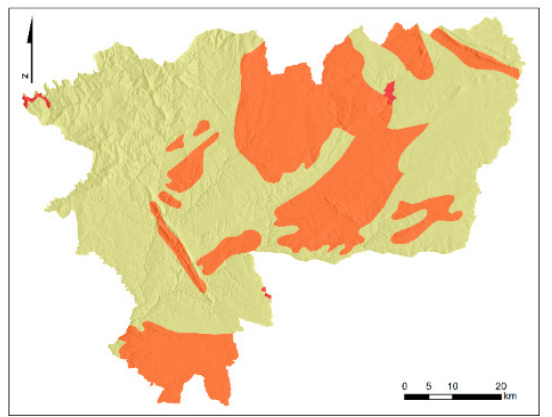

(d)

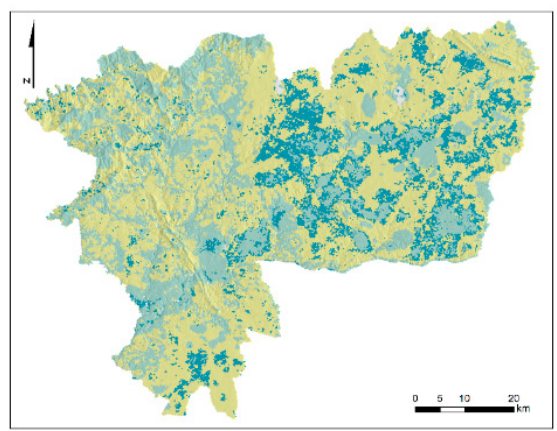

(g)

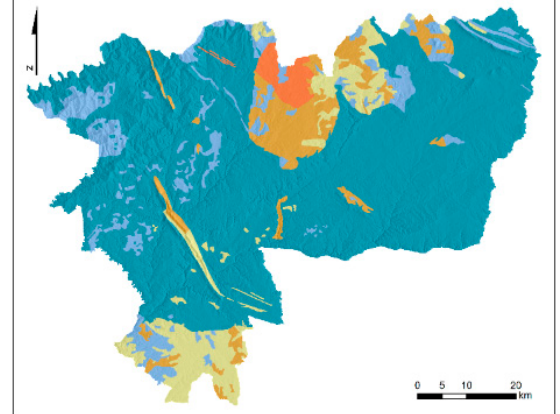

(b)

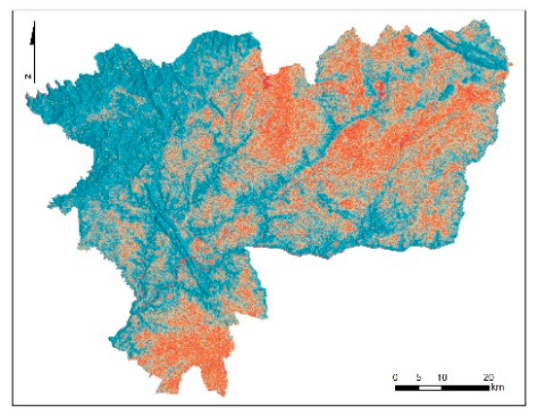

(e)

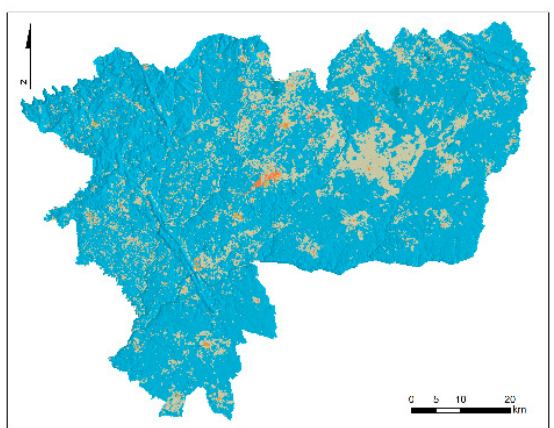

(h)

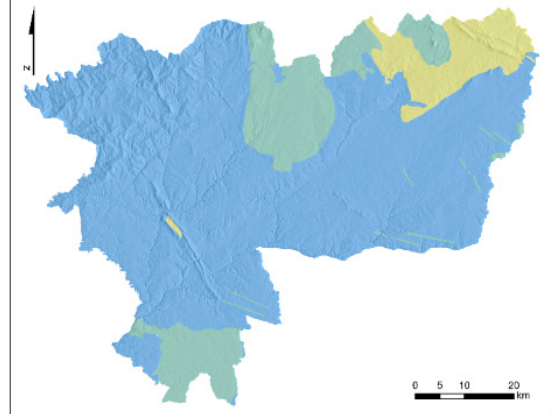

(c)

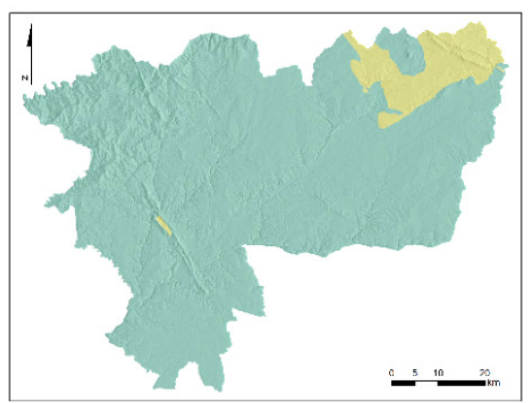

(f)

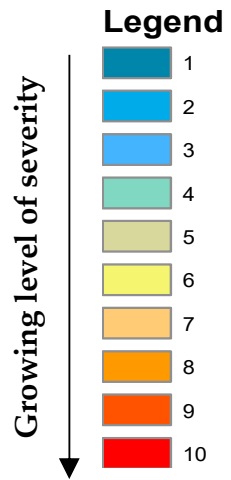

Figure 3. DRASTIC and DRASTICAI layer attributes: (a) depth; (b) recharge; (c) aquifer media; (d) soil media; (e) topography (slope); (f) impact of the vadose zone; (g) hydraulic conductivity; and (h) anthropogenic influence. 
For the further calculation of the indices DRASTIC and DRASTICAI, eight thematic maps were compiled as shown in Figure 3.

\section{Results}

The index DRASTIC was constructed using Equation (1). The obtained results were classified into different classes corresponding to low (54-119, 87.9\%), intermediate (119-149, $10.4 \%)$, and high vulnerability (149, 1.7\%; Figure 4a). The DRASTICAI index was compiled based on the DRASTIC index using Equation (2). The DRASTICAI index considers the reclassification of the obtained results into different classes corresponding to low vulnerability $(53-119,65.8 \%)$, intermediate vulnerability $(119-149,28.4 \%)$, and high vulnerability $(149,5.8 \%$; Figure $4 b)$.

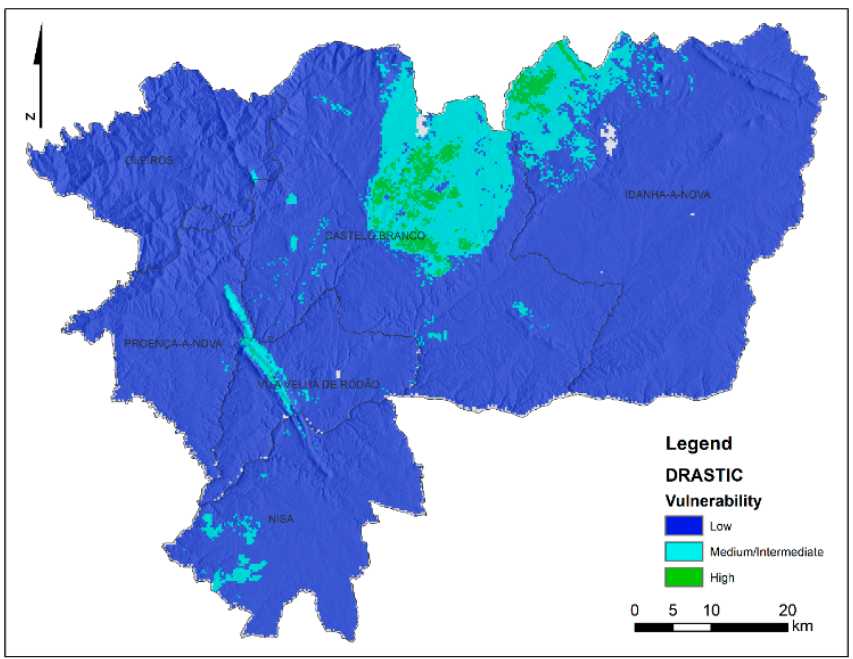

(a)

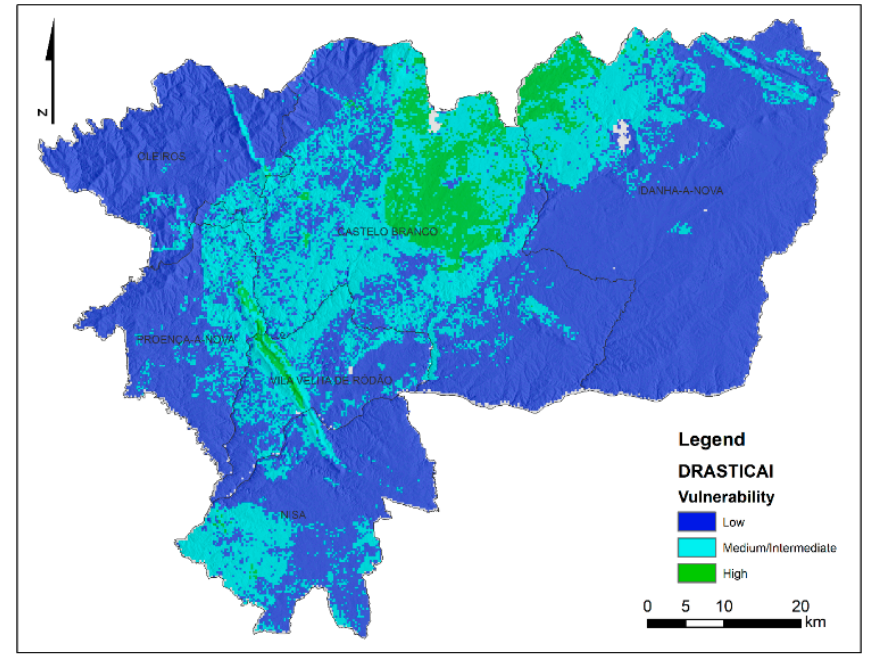

(b)

Figure 4. DRASTIC (a) and DRASTICAI (b) maps.

The risk map DRASTIC highlights two different levels of vulnerability: low $(87.9 \%$ of the total area) and moderate (10.4\% of the total area) (Figure 4a). The northern areas, Idanha-a-Nova and Castelo Branco, show low vulnerability (105-119), while the rest of the area is moderately vulnerable (120-138). However, when analyzing the DRASTICAI map, it is possible to detect significant changes in the spatial patterns of vulnerability (Figure $4 \mathrm{~b}$ ). Three levels of increasing vulnerability, from low to high, can be identified. The municipality of Idanha-a-Nova is the most affected by anthropogenic influence due to intensive agricultural activities.

\section{Discussion}

Land use parameters can significantly affect groundwater quality. Anthropogenic factors affecting water quality in rural areas differ from those in urban areas. In rural areas, these include agricultural practices, such as the use of fertilizers, herbicides, and pesticides; siltation of streams through erosion; nutrient loading of water bodies; runoff from degraded forest land; and livestock production. Changes in land cover, and especially in land use patterns, play an important role in water flow and, consequently, in water quality [36,37]. The studied area is mainly intensively used for agriculture, which raises important issues related to groundwater monitoring and quality assessment (Figure 3). Indeed, groundwater resources in areas of high agricultural use generally have higher nitrate levels, leading to water quality degradation and high non-carcinogenic risk to human health [38-43]. Therefore, increasing attention is being paid worldwide to the identification of effective approaches aimed at prevention and management solutions for groundwater pollution assessment and water safety [40]. 
The index DRASTIC shows a predominantly low/moderate vulnerability $(87.9 \%)$ and, thus, a reassuring geological and hydrogeological framework that provides natural protection against groundwater pollution. However, when the anthropogenic influence is considered using land-use parameters, the calculated index (DRASTICAI) shows a moderate-high vulnerability, increasing from $12.1 \%$ to $34.2 \%$, indicating a high risk due to human influence. Here, the more vulnerable areas coincide with agricultural and urban areas.

The algebraic subtraction between the maps DRASTIC and DRASTICAI shows an important contribution of anthropogenic influence (Figure 5). It is possible to mention an increasing effect from low/moderate to high vulnerability in the whole studied area, but specifically in the municipality of Idanha-a-Nova.

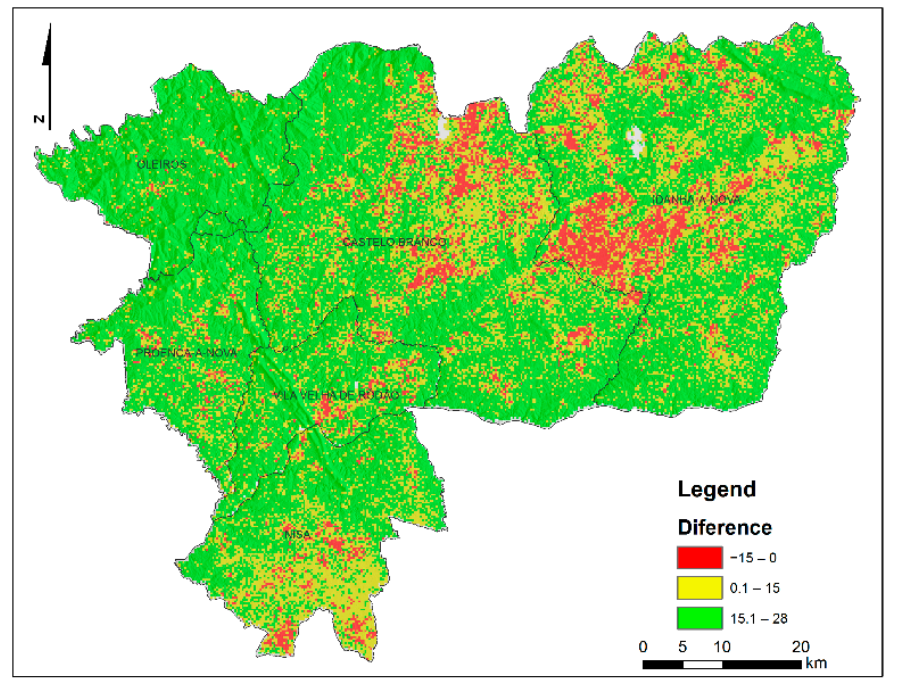

(a)

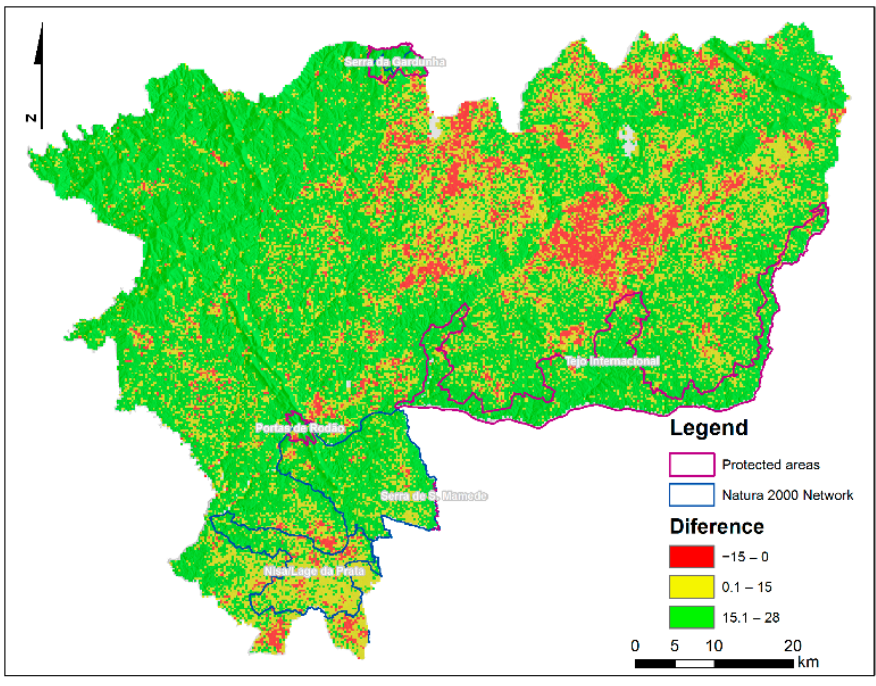

(b)

Figure 5. Algebraic subtraction between the DRASTIC and DRASTICAI (a) municipalities within the study area, (b) protected areas, and Natura 2000 Network areas overlap.

In conclusion, it is important to emphasize that an understanding of field conditions associated with human activities provides a robust assessment of groundwater quality and plays a fundamental role in decision making and establishing effective management strategies for groundwater monitoring and abstraction.

Future developments include extending the methods studied to other neighboring areas to assess groundwater quality at a regional scale [37,42,43].

\section{Conclusions}

Groundwater is an essential and strategic resource for social and human development, especially in regions with water scarcity and cyclical droughts under climate change scenarios. This study aimed to assess the vulnerability of groundwater to pollution in the Naturtejo Geopark area using a modified DRASTIC index-DRASTICAI. This new index was constructed by adding a new attribute called anthropogenic influence. The spatial patterns of DRASTICAI show a clear influence of anthropogenic activities, mainly in the community of Idanha-a-Nova, which is an area of intensive olive tree production with high levels of water abstraction. Therefore, an urgent need to develop efficient management strategies for the sustainable use and protection of groundwater resources is needed. For this purpose, it is imperative to have appropriate tools for effective monitoring and assessment of groundwater resources and abstraction control at the watershed scale. Effective management is critical for the sustainable management of groundwater resources.

Water is one of the most strategic resources in the world. Portugal has significant groundwater resources that can be of strategic importance for the expected dry years. 
Supplementary Materials: The following are available online at https://www.mdpi.com/article/10 .3390 /geosciences11060228/s1, Figure S1. Source Parameters layers.

Author Contributions: Conceptualization, T.A. and N.R.; methodology, T.A. and N.R.; software, N.R.; validation, T.A., and N.R.; formal analysis, T.A. and N.R.; investigation, T.A., N.R., J.R., M.A., and C.S.; resources, T.A., N.R., J.R., M.A., and C.S.; data curation, T.A.; writing, T.A., N.R., J.R., M.A., and C.S.; visualization, T.A., N.R., J.R., M.A., and C.S.; supervision, T.A.; project administration, T.A.; funding acquisition, T.A. and M.A. All authors have read and agreed to the published version of the manuscript.

Funding: This research was funded by FCT-Fundação para a Ciência e a Tecnologia, I.P., Portugal, grants numbers UIDB/04683/2020, UIDP/04683/2020 (ICT) and UIDB/00681/2020 (CERNAS-IPCB) and the QRural-Instituto Politécnico de Castelo Branco research center.

Institutional Review Board Statement: Not applicable.

Informed Consent Statement: Not applicable.

Data Availability Statement: The data supporting reported results can be found: The data supporting the Depth was recollected in SNIRH (https://snirh.apambiente.pt/) and IGEM (http://info. igme.es/BDAguas), data from Portugal and Spain respectively $[25,26]$. The data for the Recharge is available in ARH Tejo (https:/ / sniamb.apambiente.pt/content/cat\%C3\%A1logo) [27,28]. Geological Map is disponible in Global Lithological Map database v1.1 (https:/ / www.geo.uni-hamburg.de/ en/geologie/forschung/geochemie/glim.html) [29]. Soil Map provided by the FAO-Harmonized World Soil Database v 1.2 (http:/ / www.fao.org/soils-portal/data-hub/soil-maps-and-databases / harmonized-world-soil-database-v12/en/) [30]. The elevation was driven bay Global Digital Elevation Model (https://lpdaac.usgs.gov/products/astgtmv003/) [31]. The data for the Hidraulik conductivity wase provide by 3D Hydraulic DB (https:/ / esdac.jrc.ec.europa.eu/content/3d-soilhydraulic-database-europe-1-km-and-250-m-resolution) [29,31,32]. The Land Use is provided by COS 2018 (https: / /www.dgterritorio.gov.pt/Carta-de-Uso-e-Ocupacao-do-Solo-para-2018) [34]. The study area is driven from CAOP 2020 (https:/ / www.dgterritorio.gov.pt/cartografia/cartografiatematica/caop) [33].

Acknowledgments: The authors acknowledge FCT—Fundação para a Ciência e a Tecnologia, I.P., and the QRural-Instituto Politécnico de Castelo Branco research center, Portugal, for all the support.

Conflicts of Interest: The authors declare no conflict of interest.

\section{References}

1. Abdullah, T.O.; Ali, S.S.; Al-Ansari, N.A.; Knutsson, S. Possibility of groundwater pollution in Halabja saidsadiq hydrogeological Basin, Iraq using modified DRASTIC model based on AHP and tritium isotopes. Geosciences 2018, 8, 236. [CrossRef]

2. Al-Madhhachi, A.S.T.; Rahi, K.A.; Leabi, W.K. Hydrological impact of ilisu dam on Mosul Dam; the river Tigris. Geosciences 2020, 10, 120. [CrossRef]

3. Roque, N.; Antunes, I.M.H.R.I.; Albuquerque, M.T.D.T.D. Modelação Geoquímica: Uma ferramenta de gestão ambiental. II J. Potencial Científico e Técnico do IPCB 2013, 46-47.

4. Awawdeh, M.; Obeidat, M.; Zaiter, G. Groundwater vulnerability assessment in the vicinity of Ramtha wastewater treatment plant, North Jordan. Appl. Water Sci. 2015, 5, 321-334. [CrossRef]

5. Babiker, I.S.; Mohamed, M.A.A.; Hiyama, T.; Kato, K. A GIS-based DRASTIC model for assessing aquifer vulnerability in Kakamigahara Heights, Gifu Prefecture, central Japan. Sci. Total Environ. 2005, 345, 127-140. [CrossRef] [PubMed]

6. Singh, A.; Srivastav, S.K.; Kumar, S.; Chakrapani, G.J. A modified-DRASTIC model (DRASTICA) for assessment of groundwater vulnerability to pollution in an urbanized environment in Lucknow, India. Environ. Earth Sci. 2015, 74, 5475-5490. [CrossRef]

7. Voudouris, K.; Mandrali, P.; Kazakis, N. Preventing groundwater pollution using vulnerability and risk mapping: The case of the florina basin, NW Greece. Geosciences 2018, 8, 129. [CrossRef]

8. Stigter, T.Y.; Ribeiro, L.; Dill, A.M.M.C. Evaluation of an intrinsic and a specific vulnerability assessment method in comparison with groundwater salinisation and nitrate contamination levels in two agricultural regions in the south of Portugal. Hydrogeol. J. 2006, 14, 79-99. [CrossRef]

9. Aller, L.; Bennett, T.; Lehr, J.H.; Petty, R.J.; Hackett, G. DRASTIC: A Standardized System for Evaluating Ground Water Pollution Potential Using Hydrogeologic Settings; US Environmental Protection Agency: Washington, DC, USA, $1987 ;$ p. 455.

10. Antunes, I.M.H.R.; Albuquerque, M.T.D.; de Oliveira, S.F.; Roque, N.M.; Seco, M.d.F.M.; Hoyuela, A.; Alonso, L. Riscos e vulnerabilidades na bacia do rio Águeda. In Cuenca del Río Águeda: Un Territorio para dos Países; Sánchez-Bordona, F.C., Ed.; Servicio de Publicaciones, Universidad Europea Miguel de Cervantes: Valladolid, Spain, 2014; p. 92. ISBN 9788494176036. 
11. Albuquerque, M.T.D.; Sanz, G.; Oliveira, S.F.; Martínez-Alegría, R.; Antunes, I.M.H.R. Spatio-Temporal Groundwater Vulnerability Assessment-A Coupled Remote Sensing and GIS Approach for Historical Land Cover Reconstruction. Water Resour. Manag. 2013, 27, 4509-4526. [CrossRef]

12. Stigter, T.Y.; Ribeiro, L.; Carvalho Dill, A.M.M. Application of a groundwater quality index as an assessment and communication tool in agro-environmental policies - Two Portuguese case studies. J. Hydrol. 2006, 327, 578-591. [CrossRef]

13. Rodrigues, J.; Canilho, S.; Neto De Carvalho, C. Património Geológico Do Geopark Naturtejo: Aplicações Ao Ensino De Hidrogeologia E Geoquímica E From Naturtejo Geopark: Appli for Learning Hydrogeology and Geochemistry. In Proceedings of the VIII Congresso Ibérico de Geoquímica, Castelo Branco, Portugal, September 2011; Livro de Resumos, pp. 1-7.

14. Cunha, S.; Silva, á.; Herráez, C.; Pires, V.; Chazarra, A.; Mestre, A.; Nunes, L.; Mendes, M.; Neto, J.; Marques, J.; et al. Atlas Climático Ibérico-Iberian Climate Atlas; Agencia Estatal de Meteorología-Ministerio de Medio Ambiente y Medio Rural y Marino, Ed.; Ministerio de Medio Ambientale: Madrid, Spain, 2011; ISBN 9788478370795.

15. Sequeira, A. Provável discordância intra Grupo das Beiras na região entre Monfortinho e Idanha-a-Velha. In Proceedings of the XII Reunião do Oeste Peninsular, Evora, Portugal, 20-24 September 1994; pp. 41-52.

16. Romão, J.A. Boletin Geol. y Minero de Espanha; Instituto Geológico y Minero de España: Madrid, Spain, 1994; pp. 521-530.

17. Oliveira, J.T.; Pereira, E.; Picarra, J.M.; Young, T.; Romano, M.; Liso Rubio, M.J. O Paleozoico inferior de Portugal: Sintese da estratigrafia e da evolucao paleogeografica. In Paleozóico Inferior de Ibero-América; Universidad de Extremadura: Badajoz, Spain, 1992; pp. 359-376.

18. Oliveira, J.T.; Pereira, E.; Picarra, J.M.; Young, T.; Romano, M.; Liso Rubio, M.J.; Piçarra, J.M.; Young, T.; Romano, M. O Paleozóico Inferior de Portugal: Síntese da estratigrafia e da evolução paleogeográfica. In Paleozóico Inferior de Ibero-América; Universidad de Extremadura: Badajoz, Spain, 1992; pp. 359-375.

19. Antunes, I.M.H.R.; Neiva, A.M.R.; Silva, M.M.V.G.; Corfu, F. Geochemistry of S-type granitic rocks from the reversely zoned Castelo Branco pluton (central Portugal). Lithos 2008, 103, 445-465. [CrossRef]

20. Neiva, A.M.R.; Campos, T.F.C. Genesis of the zoned granitic pluton of Penamacor-Monsanto, Central Portugal. Mem. Not. Publ. Mus. Lab. Miner. Geol. Univ. Coimbra 1992, 114, 51-68.

21. Portugal Ferreira, M.; Ivo Alves, E.; Regencio Macedo, C.A. A zonalidade interna de um plutonito: Estruturas condicionantes e idades de evolucao (plutonite do Fundao, Portugal Central). Memorias e Not. Publicacoes do Mus. e Lab. Mineral. e Geol. da Univ. Coimbra 1985, 99, 167-187.

22. Teixeira, C.; Carvalho, H.F.; Santos, J.P. Carta Geológica de Portugal. 20-B; Serviços Geológicos de Portugal: Lisboa, Portugal, 1975.

23. Antunes, I.M.H.R.; Neiva, A.M.R.; Silva, M.M.V.G.; Corfu, F. The genesis of I- and S-type granitoid rocks of the Early Ordovician Oledo pluton, Central Iberian Zone (central Portugal). Lithos 2009, 111, 168-185. [CrossRef]

24. Cunha, P.P. Unidades litostratigráficas do Terciário da Beira Baixa (Portugal). Comun. do Inst. Geológico e Min. 1996, 82, 87-130.

25. SNIRH. APAmbiente SNIRH Dados de Base. Available online: https://snirh.apambiente.pt/index.php?idMain=2\&idItem=1 (accessed on 6 October 2020).

26. IGME. BD Puntos Agua v2.0. Available online: http://info.igme.es/BDAguas (accessed on 6 October 2020).

27. ARH. Plano de Gestao da Regiao Hidrografica do Tejo; ARH do Tejo, I.P.: Lisbon, Portugal, 2011; 493p.

28. Lobo-Ferreira, J.P.; Leitão, T.E.; Oliveira, M.M. Portugal's river basin management plans: Groundwater innovative methodologies, diagnosis, and objectives. Environ. Earth Sci. 2015, 73, 2627-2644. [CrossRef]

29. Hartmann, J.; Moosdorf, N. (2012): Global Lithological Map Database v1.0 (gridded to $0.5^{\circ}$ spatial resolution). doi:10.1594/ PANGAEA.788537., Supplement to: Hartmann, J.; Moosdorf, N. The new global lithological map database GLiM: A representation. Geochem. Geophys. Geosyst. 2012, 13. [CrossRef]

30. Fischer, G.; Nachtergaele, F.; Prieler, S.; van Velthuizen, H.T.; Verelst, L.; Wiberg, D. FAO SOILS PORTAL: Harmonized World Soil Database v1.2; Food and Agriculture Organization of the United Nations: Rome, Italy, 2019.

31. NASA/METI/AIST/Japan Spacesystems; U.S./Japan ASTER Science Team. ASTER Global Digital Elevation Model V003 [Data Set]; NASA EOSDIS Land Processes DAAC: Sioux Falls, SD, USA, 2018.

32. Tóth, B.; Weynants, M.; Nemes, A.; Makó, A.; Bilas, G.; Tóth, G. New generation of hydraulic pedotransfer functions for Europe. Eur. J. Soil Sci. 2015, 66, 226-238. [CrossRef]

33. Tóth, B.; Weynants, M.; Pásztor, L.; Hengl, T. 3D soil hydraulic database of Europe at $250 \mathrm{~m}$ resolution. Hydrol. Process. 2017, 31, 2662-2666. [CrossRef]

34. Meneses, B.M. A Caraterização do uso e Ocupação do Solo de Portugal Continental; DGT: Enschede, The Netherlands, 2014.

35. Januário, P.; Neto, J.; Costa Roque, C. Carta administrativa oficial de Portugal (CAOP). Mapping 2008, 31, 36-38.

36. Khatri, N.; Tyagi, S. Influences of natural and anthropogenic factors on surface and groundwater quality in rural and urban areas. Front. Life Sci. 2015, 8, 23-39. [CrossRef]

37. Liu, J.; Peng, Y.; Li, C.; Gao, Z.; Chen, S. An investigation into the hydrochemistry, quality and risk to human health of groundwater in the central region of Shandong Province, North China. J. Clean. Prod. 2021, 282, 125416. [CrossRef]

38. Seifi, A.; Dehghani, M.; Singh, V.P. Uncertainty analysis of water quality index (WQI) for groundwater quality evaluation: Application of Monte-Carlo method for weight allocation. Ecol. Indic. 2020, 117, 106653. [CrossRef]

39. Fan, B.L.; Zhao, Z.Q.; Tao, F.X.; Liu, B.J.; Tao, Z.H.; Gao, S.; Zhang, L.H. Characteristics of carbonate, evaporite and silicate weathering in Huanghe River basin: A comparison among the upstream, midstream and downstream. J. Asian Earth Sci. 2014, 96, 17-26. [CrossRef] 
40. Shirazi, S.M.; Imran, H.M.; Akib, S.; Yusop, Z.; Harun, Z.B. Groundwater vulnerability assessment in the Melaka State of Malaysia using DRASTIC and GIS techniques. Environ. Earth Sci. 2013, 70, 2293-2304. [CrossRef]

41. Heiß, L.; Bouchaou, L.; Tadoumant, S.; Reichert, B. Index-based groundwater vulnerability and water quality assessment in the arid region of Tata city (Morocco). Groundw. Sustain. Dev. 2020, 10. [CrossRef]

42. Fang, Y.; Zheng, T.; Zheng, X.; Peng, H.; Wang, H.; Xin, J.; Zhang, B. Assessment of the hydrodynamics role for groundwater quality using an integration of GIS, water quality index and multivariate statistical techniques. J. Environ. Manage. 2020, 273. [CrossRef] [PubMed]

43. Gaikwad, S.K.; Kadam, A.K.; Ramgir, R.R.; Kashikar, A.S.; Wagh, V.M.; Kandekar, A.M.; Gaikwad, S.P.; Madale, R.B.; Pawar, N.J.; Kamble, K.D. Assessment of the groundwater geochemistry from a part of west coast of India using statistical methods and water quality index. HydroResearch 2020, 3, 48-60. [CrossRef] 